\title{
Evaluations of the Effect of Workshop/Laboratory Accidents and Precautionary Steps towards Safety Practice"
}

\author{
${ }^{1}$ Osang, Jonathan Eyire, ${ }^{2}$ Obi, Emmanuel O ${ }^{3}$ Ewona, Igwe O. \\ Cross River State University Of Technology, Nigeria. (That Is, Three Persons)
}

\begin{abstract}
A good number of scientist, engineers, laboratory or workshop users have lost their lives and the lives of others due to accidents in the workshop caused by ignorance, neglect or carelessness. This paper focus on the incident and prevalence rate of workshop and laboratory accidents in twenty (20) schools within Cross River State, Nigeria. The investigation took place between January 2008 and December 2012 (a period of five years). A total of 66 departments were investigated. The data was source with the help of the technologist and head of Department of each of the schools. Based on these data, using descriptive analysis, multiple bar chart and Trend analysis (Analysis of variance-SPSS) to show the growth and decline of laboratory or workshop accidents across various departments over the years of study. The result revealed that the average number of accidents occurred most in chemistry department; UNICAL and CRUTECH at 25 and 18 respectively, (table 1 and 2). And that of 18 secondary schools indicated that Bekwara Local Government Area was the highest numbers of accidents (20.0) table 3, while Biase Local Government Area had the least (10.2), physics and biology had recorded less accidents (table 3). In the two universities, computer/Maths statistic Department had less laboratory accident due to not being exposed to heavy chemical. Hence, from this result, 40 workshop safety and precautionary steps are release to avoid or minimize accidents in the laboratory or workshop towards a healthy carrier.
\end{abstract}

Key Word: workshop accidents, Technology, Scientist, Engineers, Safety and precautions

\section{Introduction}

Over the year, both in develop and developing countries, technology has been a standard of differentiating factor between countries state, organizations and individual irrespective of the colour, culture or language. And as such, technology depends on the quality of scientist, engineers, and laboratory or workshop users. Technology can never be successful without the workshop, laboratory or tools. According to Thomas Carlyle, man without tools is nothing, with tool he is all, this statement elaborated the important of tooling to a man.

The important of laboratory workshop and tools cannot be over emphases. Move over, research have it that, the workshop or laboratory claim too many victims (lives) in the process of carrying out research or during the use of machines. Over 70\% of these accidents are caused by neglect, carelessness or ignorance on the part of the scientist, engineer, (student) or a colleague in the workshop or laboratory.

In 2008, a first year student in Cross River University of technology-Nigeria was rushed to the hospital during a practical experiment in chemistry laboratory due to an exploration which was wrongly mixed by self. In 2010, a final year student in Boki comprehensive secondary school Okundi was badly injured during a practical class by a friend who was terribly drunk.

That not withstanding, a good number of scientist, engineer, a laboratory or workshop user have lost their hands, legs, eyes, ears, mouth, fingers, carriers, marriages, jobs, education, friends, their lives and the lives of others due to neglect, carelessness or ignorance of laboratory or workshop safety and precautions in cases of accidents.

\section{Radioactive Hazards In The Laboratory}

In the workshop/Laboratory, Radioactive contamination is also called radiological contamination. It is the deposition of or presence of radioactive substance on surface or within solids, liquids, or gases (including the human body), where their presence is unintended or undesirable. Such contamination presents a hazard because of the radioactive decay of the contaminants, which emit harmful ionizing radiation such as alpha or beta particles, gamma rays or neutrons. The degree of hazard is determined by the concentration of the contaminants, the energy of the radiation being emitted, the type of radiation and the proximity of the contamination to organs of the body. It is very important to be clear that the contamination gives rise to the radiation hazard, and the terms radiation and contamination are not interchangeable. Contamination may affect a person, a place, environment, animal, an object such as clothing. 
Radiation contamination is typically the result of a spill or accident during the production, or use of radionuclides (radioisotopes). Clearing up contamination result in radioactive waste. If a person's body is contaminated by ingestion or by injury and standard clearing cannot reduce the contamination further, then the person may be permanently contaminated.

Radioactive contamination can enter the body through ingestion, inhalation, absorption or injection. For this reason, it is very important to use personal protective equipment when working with radioactive materials.

\section{Geography of the area:}

\section{Materials and Method}

Cross River State is one Nigeria's coastal State, located in the south-south region of the county, bordered by the Republic of Cameroon in the East and Nigeria state of Benue (North), Ebonyi and Abia (West) and Akwa Ibom (south-west ). It occupies a total land area of 20,156 square kilometers, lying between latitude $4^{0} 28^{0}$ and $6^{0} 55^{\circ}$ North of the equator and green wich meridian. It has the average of 2,311297 people. Cross River State was created in May 27, 1967, named for Cross River (Oyono) which passes through the Sate located in the Niger Delta. The State has its capital at Calabar. And is composed of three major ethnic groups, the Efik, the Ejagham and Bekwara. Cross River State is divided into eighteen (18) local Government Area namely; Akpabuyo, Odukpani, Akamkpa, Biase, Ikom, Yarkuur, Obubra, Boki, Ogoja, Calabar-south, Etung, Bekwara, Bakassi, Calabar municipality. Obanliku, Obudu, Yala, Abi.

\section{Method}

The method of analysis to the study on evaluation of the effect of workshop/Laboratory accidents and precautionary steps toward safety practice. The description method of analysis was employed to show and indicate the growth and decline of laboratory accident across various department over the years of study.

Analysis of variance was carried out to study the significance different on the department in the university. Moveover, multiple bar charts and trend analysis was done to show or indicate the movement or growth of laboratory accidents across Local Government Area in the State (Cross River).

\section{Data source:}

Twenty (20) schools were chosen for this study. Two universities in the state (university of Calabar UNICAL and Cross River University of technology-Nigeria (CRUTECH) and eighteen (18) secondary schools in the eighteen (18) local government area in Cross River State, Nigeria. Records of all the accidents that occur (major and minor) through the help of chief laboratory technologist and Head of Department. This was done to investigate the level of workshop laboratory accidents in each of the schools and departments respectively.

\begin{tabular}{|c|c|c|}
\hline \multicolumn{3}{|c|}{ DIFINTION OF TERMS } \\
\hline UNICAL & $=$ & University of Calabar \\
\hline CRUTECH & $=$ & Cross River University of Technology Nigeria \\
\hline GTCI & $=$ & Government Technical collage Ikot Nakanda-Akpabuyo L.G.A \\
\hline GSSO & $=$ & Government secondary school Akpap Okoyong-Odukpani L.G.A \\
\hline GSSA & $=$ & Government secondary school. Akpanmkpa. L.G.A \\
\hline GSSB & $=$ & Government secondary school-Biase L.G.A \\
\hline BSC & $=$ & Bekwara secondary school, Bekwara LGA. \\
\hline FGCI & $=$ & Federal Government Collage-Ikom L.G.A \\
\hline BCSSO & $=$ & Boki Comprehensive secondary school-Okundi Boki L.G.A \\
\hline FSCO & $=$ & Federal Science Collage Ogoja-L.G.A. \\
\hline GSSIB & $=$ & Government secondary school Ikang-Bakassi L.G.A \\
\hline CSB & $=$ & Community secondary school Bugwagban Obudu L.G.A \\
\hline $\mathrm{TCO}$ & $=$ & Technical secondary school Obanliku L.G.A \\
\hline ATCE & $=$ & Ajasson Technical collage Etung L.G.A \\
\hline $\mathrm{MCO}$ & $=$ & Mary knoll Collage Okuku-Yala L.G.A \\
\hline GSSC & $=$ & Government Secondary School -Henshaw Town. Calabar South \\
\hline GSSAC & $=$ & Government Science School Akin-Calabar Municpality \\
\hline SPTU & $=$ & St. Patrick Technical collage Ugep-Yakuur L.G.A \\
\hline GSSO & $=$ & Government Science School Obubra - L.G.A \\
\hline ACSSEA & $=$ & Agbo Comprehensive secondary school Egboronyi Abi \\
\hline
\end{tabular}




\section{Results:}

Table 1. Number Of Workshop/Laboratory Accidents In University Of Calabar

\begin{tabular}{|l|l|l|l|l|l|l|}
\hline year & physics & chemistry & biology & comp/maths/stat & TOATAL & MEAN \\
\hline 2008 & 13 & 20 & 14 & 1 & 48 & 12 \\
\hline 2009 & 14 & 22 & 11 & 2 & 49 & 12.25 \\
\hline 2010 & 14 & 25 & 19 & 2 & 60 & 15 \\
\hline 2011 & 17 & 28 & 21 & 3 & 69 & 17.25 \\
\hline 2012 & 18 & 30 & 22 & 4 & 74 & 18.5 \\
\hline & 76 & 125 & 87 & 12 & & \\
\hline MEAN & 15.2 & 25 & 17.4 & 2.4 & & \\
\hline
\end{tabular}

Table 2. Anova On Number Of Workshop/ Laboratory Accidents In University Of Calabar

\begin{tabular}{|c|c|c|c|c|c|c|}
\hline & & Sum of Squares & $\mathrm{df}$ & Mean Square & $\mathrm{F}$ & Sig \\
\hline \multirow[t]{3}{*}{ Physics } & Between Groups & 18.800 & 4 & 4.700 & 1.175 . & \\
\hline & Within Groups & .000 & 0 & & & \\
\hline & Total & 18.800 & 4 & & & \\
\hline \multirow[t]{3}{*}{ Chemistry } & Between Groups & 68.000 & 4 & 17.000 & 4.25 . & \\
\hline & Within Groups & .000 & 0 & & & \\
\hline & Total & 68.000 & 4 & & & \\
\hline \multirow[t]{3}{*}{ biology } & Between Groups & 89.200 & 4 & 22.300 & 5.575 . & \\
\hline & Within Groups & .000 & 0 & & & \\
\hline & Total & 89.200 & 4 & & & \\
\hline \multirow[t]{3}{*}{$\mathrm{cmp} / \mathrm{maths} / \mathrm{stat}$} & Between Groups & 5.200 & 4 & 1.300 & 0.324 & \\
\hline & Within Groups & .000 & 0 & & & \\
\hline & Total & 5.200 & 4 & & & \\
\hline
\end{tabular}

Figure 1:THE MULTIPLE COMPARISM BAR CHART OF NUMBER OF WORKSHOP/ LABORATORY ACCIDENTS IN UNIVERSITY OF CALABAR

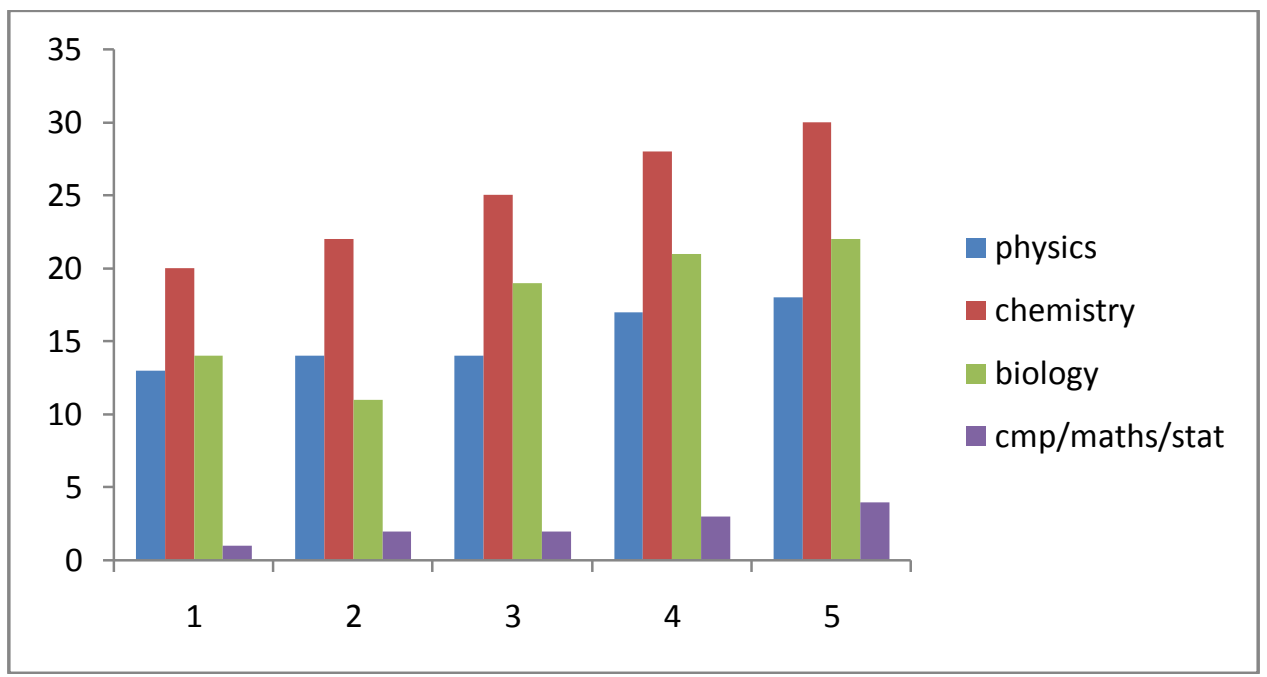


Evaluations Of The Effect Of Workshop/Laboratory Accidents And Precautionary Steps Towards

TABLE 3 NO OF WORKSHOP/LABORATORY ACCIDENT IN CROSS RIVER UNIVERSITY OF TECHNOLOGY

\begin{tabular}{|c|c|c|c|c|c|c|c|}
\hline DEPARTMENT & 2008 & 2009 & 2010 & 2011 & 2012 & TOTAL & MEAN \\
\hline physics & 10 & 12 & 13 & 15 & 20 & 70 & 14 \\
\hline chemistry & 12 & 15 & 16 & 20 & 27 & 90 & 18 \\
\hline biology & 11 & 11 & 12 & 15 & 21 & 70 & 14 \\
\hline mec engr & 11 & 12 & 14 & 17 & 25 & 79 & 15.8 \\
\hline elect engr & 8 & 11 & 11 & 9 & 15 & 54 & 10.8 \\
\hline civil engr & 6 & 7 & 9 & 11 & 12 & 45 & 9 \\
\hline wood and paper & 10 & 12 & 14 & 11 & 19 & 66 & 13.2 \\
\hline computer engr & 2 & 4 & 2 & 3 & 5 & 16 & 3.2 \\
\hline
\end{tabular}

Figure 2

THE MULTIPLE COMPARISM BAR CHART OF NUMBER OF WORKSHOP/LABORATORY

ACCIDENT IN CROSS RIVER UNIVERSITY OF TECHNOLOGY NIGERIA

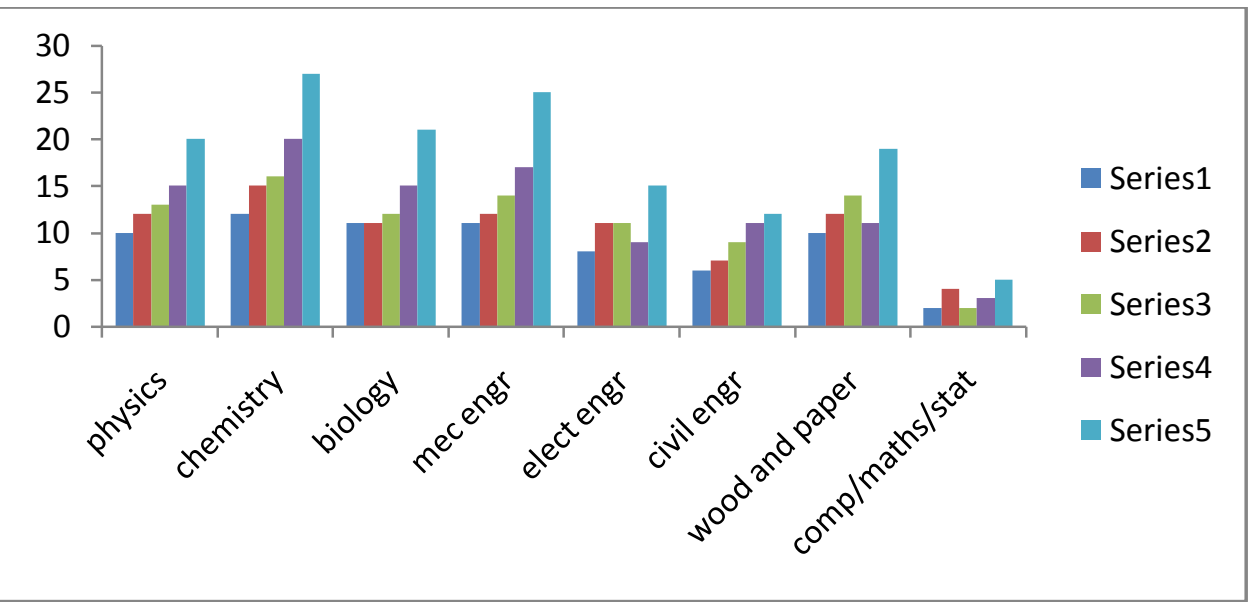

Table 4: No Of Workshop/Laboratory Accidents In 18 Secondary Schools In The 18 Local Government Areas. (Cross River State) Nigeria.

\begin{tabular}{|c|c|c|c|c|c|c|c|c|}
\hline Secondary Schools & $\mathrm{Lab}$ & 2008 & 2009 & 2010 & 2011 & 2012 & Total & Mean \\
\hline \multirow[t]{3}{*}{ Gtci } & Physics & 10 & 11 & 14 & 13 & 16 & 64 & 12.8 \\
\hline & Chemistry & 12 & 13 & 12 & 15 & 21 & 73 & 14.6 \\
\hline & Biology & 6 & 10 & 15 & 17 & 19 & 67 & 13.4 \\
\hline \multirow[t]{3}{*}{ Gsso } & Physics & 11 & 12 & 11 & 13 & 15 & 62 & 12.4 \\
\hline & Chemistry & 13 & 15 & 16 & 18 & 20 & 82 & 16.4 \\
\hline & Biology & 12 & 13 & 13 & 14 & 17 & 69 & 13.8 \\
\hline \multirow[t]{3}{*}{ Gssa } & Physics & 11 & 12 & 11 & 11 & 16 & 61 & 12.2 \\
\hline & Chemistry & 11 & 11 & 13 & 15 & 19 & 69 & 13.8 \\
\hline & Biology & 10 & 12 & 14 & 14 & 18 & 68 & 13.6 \\
\hline \multirow[t]{3}{*}{ Gssb } & Physics & 6 & 7 & 9 & 10 & 19 & 51 & 10.2 \\
\hline & Chemistry & 9 & 14 & 19 & 22 & 28 & 92 & 18.4 \\
\hline & Biology & 10 & 11 & 11 & 14 & 19 & 65 & 13 \\
\hline \multirow[t]{3}{*}{ Bsc } & Physics & 11 & 12 & 13 & 14 & 15 & 65 & 13 \\
\hline & Chemistry & 18 & 19 & 19 & 19 & 30 & 105 & 21 \\
\hline & Biology & 10 & 11 & 11 & 17 & 24 & 73 & 14.6 \\
\hline \multirow[t]{3}{*}{ Fgci } & Physics & 10 & 12 & 13 & 9 & 22 & 66 & 13.2 \\
\hline & Chemistry & 13 & 19 & 21 & 24 & 28 & 105 & 21 \\
\hline & Biology & 13 & 11 & 14 & 15 & 25 & 78 & 15.6 \\
\hline \multirow[t]{3}{*}{ Sptu } & Physics & 6 & 7 & 10 & 15 & 16 & 54 & 10.8 \\
\hline & Chemistry & 11 & 14 & 15 & 16 & 17 & 73 & 14.6 \\
\hline & Biology & 7 & 11 & 10 & 14 & 16 & 58 & 11.6 \\
\hline \multirow[t]{3}{*}{ Gsso } & Physics & 16 & 12 & 13 & 14 & 16 & 71 & 14.2 \\
\hline & Chemistry & 14 & 15 & 19 & 21 & 23 & 92 & 18.4 \\
\hline & Biology & 10 & 13 & 18 & 17 & 19 & 77 & 15.4 \\
\hline Bcsso & Physics & 11 & 12 & 13 & 15 & 20 & 71 & 14.2 \\
\hline
\end{tabular}


Evaluations Of The Effect Of Workshop/Laboratory Accidents And Precautionary Steps Towards

\begin{tabular}{|c|c|c|c|c|c|c|c|c|}
\hline & Chemistry & 14 & 16 & 20 & 23 & 27 & 100 & 20 \\
\hline & Biology & 10 & 11 & 17 & 17 & 20 & 75 & 15 \\
\hline \multirow[t]{3}{*}{ Fsco } & Physics & 11 & 12 & 13 & 15 & 20 & 71 & 14.2 \\
\hline & Chemistry & 15 & 16 & 19 & 22 & 24 & 96 & 19.2 \\
\hline & Biology & 12 & 13 & 14 & 17 & 21 & 77 & 15.4 \\
\hline \multirow[t]{3}{*}{ Gssc } & Physics & 12 & 14 & 15 & 19 & 22 & 82 & 16.4 \\
\hline & Chemistry & 14 & 17 & 20 & 22 & 26 & 99 & 19.8 \\
\hline & Biology & 13 & 15 & 15 & 16 & 21 & 80 & 16 \\
\hline \multirow[t]{3}{*}{ Acssea } & Physics & 11 & 12 & 14 & 17 & 20 & 74 & 14.8 \\
\hline & Chemistry & 13 & 15 & 17 & 18 & 21 & 84 & 16.8 \\
\hline & Biology & 10 & 11 & 11 & 15 & 19 & 66 & 13.2 \\
\hline \multirow[t]{3}{*}{ Gssib } & Physics & 11 & 15 & 15 & 15 & 18 & 74 & 14.8 \\
\hline & Chemistry & 12 & 13 & 18 & 21 & 15 & 79 & 15.8 \\
\hline & Biology & 11 & 10 & 12 & 13 & 19 & 65 & 13 \\
\hline \multirow[t]{3}{*}{$\overline{\mathrm{Csb}}$} & Physics & 6 & 10 & 11 & 15 & 19 & 61 & 12.2 \\
\hline & Chemistry & 9 & 11 & 12 & 16 & 20 & 68 & 13.6 \\
\hline & Biology & 8 & 9 & 10 & 12 & 15 & 54 & 10.8 \\
\hline \multirow[t]{3}{*}{ Tco } & Physics & 10 & 12 & 15 & 16 & 20 & 73 & 14.6 \\
\hline & Chemistry & 11 & 13 & 15 & 19 & 24 & 82 & 16.4 \\
\hline & Biology & 9 & 10 & 15 & 17 & 19 & 70 & 14 \\
\hline \multirow[t]{3}{*}{ Atce } & Physics & 11 & 12 & 17 & 20 & 22 & 82 & 16.4 \\
\hline & Chemistry & 13 & 15 & 19 & 23 & 29 & 99 & 19.8 \\
\hline & Biology & 10 & 11 & 12 & 21 & 24 & 78 & 15.6 \\
\hline \multirow[t]{3}{*}{ Mco } & Physics & 6 & 7 & 10 & 13 & 17 & 53 & 10.6 \\
\hline & Chemistry & 10 & 13 & 15 & 19 & 20 & 77 & 15.4 \\
\hline & Biology & 7 & 10 & 11 & 14 & 18 & 60 & 12 \\
\hline \multirow[t]{3}{*}{ Gssac } & Physics & 9 & 11 & 15 & 16 & 17 & 68 & 13.6 \\
\hline & Chemistry & 12 & 15 & 19 & 18 & 21 & 85 & 17 \\
\hline & Biology & 11 & 13 & 14 & 15 & 19 & 72 & 14.4 \\
\hline
\end{tabular}

Figure 3

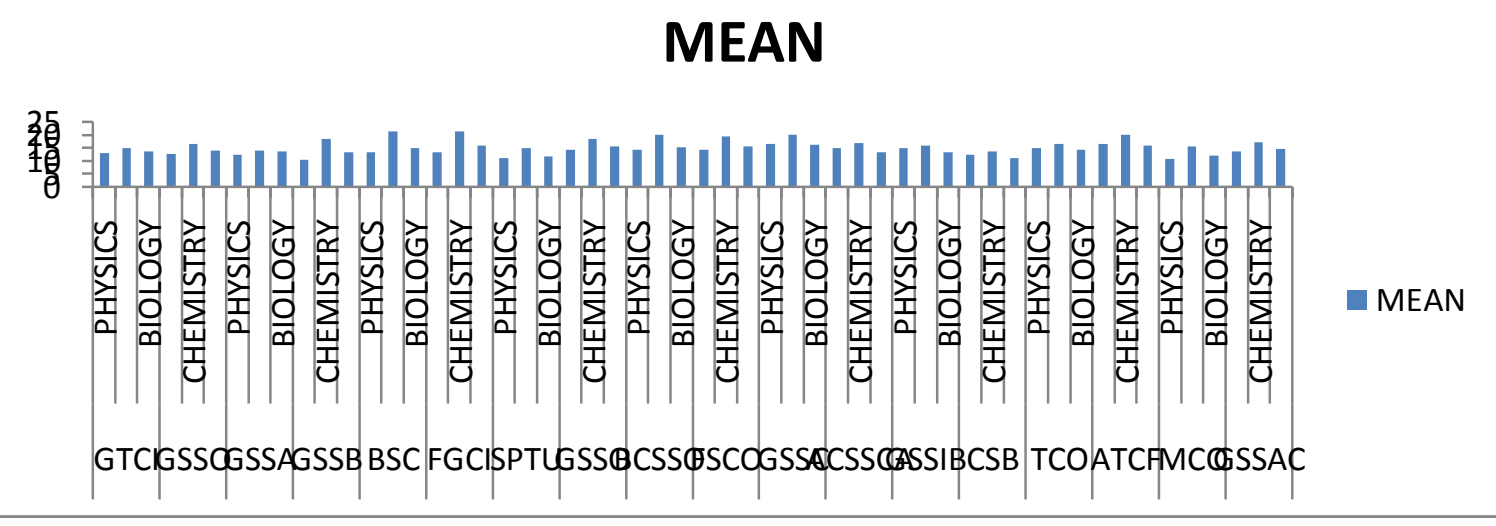

Figure 4: The trend (average) accident occurance within the 18 local Government Areas in secondary schools in Cross River State Nigeria (2008-2012)

\section{MEAN}

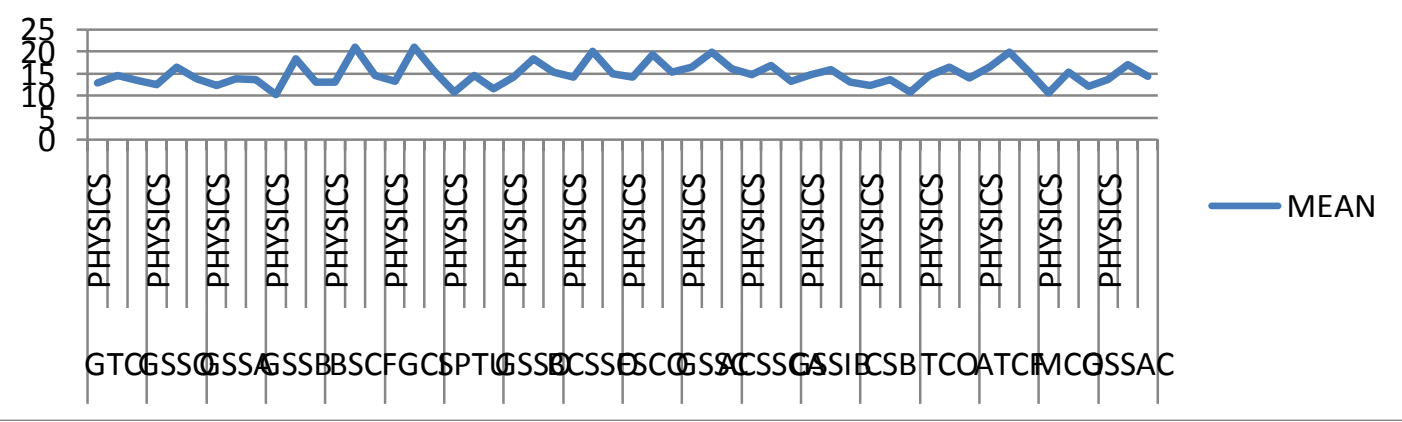




\section{Discussion of Results}

The analysis on the evaluation of the effect of workshop and laboratory accident indicates that the average number of accident occurred most in chemistry department university of Calabar over the researched years at 25 times, table 1 .

Subsequently in the further analysis there is greater significant difference across various department at $\mathrm{x}=0.05$. the result indicates that $(1.175,4.25,5.575,0.324)$ were all significant at the various department physics, chemistry, biology and computer science, Maths statistics department. The descriptive analysis on the department in crutech also indicate that chemistry department was exposed more to the laboratory accident over all the years of study with the average number of 18 times, table2. The result indicate that those in the computer science, mathematics and statistics department has less laboratory accident due to not being exposed to heavy chemicals, radioactive hazard etc.

The analysis of laboratory/workshop accidents in 18 secondary schools indicates that Bekwara secondary school in Bekwara Local Government has the average laboratory accident of 21.0 (chemistry) due to the remote locating of the school and level of ignorance. The least of 10.2 (physics) occurred in Government secondary school at Biase Local Government Area of Cross River.

\section{Conclusion}

Hence, from the result, 40 workshop safety and precautionary steps are release to avoid or minimize accidents in the laboratory or workshop towards a healthy carrier.

\section{Safety Rules/Precaution}

[1]. You must know how to read and write and able to communicate to others.

[2]. The rules must be carefully pasted or presented in a hand book available for all the workshop/laboratory users.

[3]. You must read carefully and understand all the rules before using the workshop.

[4]. Always listen carefully to the teachers and follow instructions.

[5]. Do not run in the workshop.

[6]. Know were the emergency stop buttons are positioned in the workshop.

[7]. Always wear an apron or lap coat as it will protect your clothes and skin.

[8]. Wear good strong shoes plus thick soles

[9]. Bags should not be brought into a workshop as people can trip over them.

[10]. When learning how to use a machine or an equipment, listen very carefully to all the instructions given by the teacher. Ask questions especially if not fully understand.

[11]. Do not use a machine if you have not been shown how to operate it.

[12]. Be sure that all machine's have effective and properly working guard that are always in place where machine's are operating.

[13]. Replace guards immediately after any repair or repair in progress.

[14]. Don't oil or grease any machine while it is running.

[15]. Don't try to stop any machine with your hand or body.

[16]. Keep the floor clean of metal clips or curls and waste pieces, put them in container provided for such things.

[17]. Don't rest against the machine.

[18]. Get first aid immediately for any injury.

[19]. Be sure you have sufficient light to see clearly check with

[20]. Always wear safety glasses, or face shields designed for the

[21]. Don't wear rings, watches, braslets or other jewllery that

[22]. Keep the flow free of oil, grease or any other liquid. Always

[23]. The workshop should always by well arrange in a protective

[24]. Safety goggles are very important.

[25]. Eating is not allow in the workshop.

[26]. Making calls or receiving calls in not allow in the workshop.

[27]. No smoking is allow in the workshop.

[28]. Make sure you or your fellow worker is not drunk before

[29]. Never work while tired or taking medication.

[30]. Try not to rush the job.

[31]. Avoid distractions never surprise someone who is working

[32]. Wear a nose mask.

[33]. Wear a head-net.

[34]. Never let children play in the workshop.

the supervisor if you don't enough.

type of the work operating any machine. could get caught in moving machinery. clear up the workshop.

manner.

using the workshop.

with tools. 
[35]. Turn off the power source before closing the workshop.

[36]. Never work with unprotected cut or break in the skin, particularly on the heads or forearms.

[37]. Never use any mouth operated equipment in any area where unsealed radioactive materials is used.

[38]. Label all containers clearly indicating nucide, compound, specific activity, total activity, date and name of user. Containers should be properly sealed.

[39]. Understand the nature of the hazard and get practical training.

[40]. Plan ahead to minimize time spent handling radioactivity.

[41]. The workshop attendance or anybody in charge should make sure all this rules are 100 percent guided the users.

\section{Reference}

[1]. Data on radioactive isotopes www.microbiol.unimlb.edu.au/staff/ehs/isotope/index.htw.

[2]. Environment Health and Safety management Guide (2007) santos, www.slideshare:Retrieved on 06/05/2013. 06:25pm

[3]. Hazard symbol en.wikipedia.org/hazard-symbol retrieved on 09/05/2013. 06:30pm

[4]. Radioactive contamination en.wkipedia.org/wiki radioactive contamination retrieved 08/05/2013 02:30pm.

[5]. Radioactive hazard www.google.com.ng retrieved on 09/05/2013.05:30pm

[6]. Safe and secure www.microbiol.unimelb.edu.au/staff/ehs/isotope/10goldrules retrieved on 09/05/2013. 02:00pm

[7]. Safety Catch; Safety training and consulting: by Mr. anil Gopinath www.safetycoursesindia.com Retrieved 06/05/2013 6:23pm

[8]. Welcome to Safety + preventing Banana skin situation http://www.safety one plus Retrieved 07/05/2013 10:30am.

[9]. Workplace Safety Resource, www.knowledgeatwork.com Retrieved 06?05/2013 06:30pm. 